Fiscaoeconomia

E-ISSN: 2564-7504

2021, Volume 5, Issue 2, 756-768

https://dergipark.org.tr/tr/pub/fsecon
Research Article/Araştırma Makalesi

Submitted/Geliş: 05.03.2021

Accepted/Kabul: 09.05.2021

Doi: $10.25295 /$ fsecon. 891984

\title{
Mutfak Çalışanlarının Yaratıcılık Algı Düzeyleri Üzerine Bir Araştırma
}

\section{An Investigation on the Creativity Perception Levels of Culinary Employees \\ Yener OĞAN ${ }^{1}$}

\section{Öz}

Düşünce ve hayal gücünden yararlanarak yeni bir ürün ortaya çıkmasında etkili olan yaratıııık kavramı, çalışma ortamında yenilikçi bir anlayışın gelişmesine katkı sağlamaktadır. Bu yenilikçi anlayışın geliş̧mesinde yiyecek içecek hizmetleri alanındaki mutfak çalışanlarının yaratııılık düzeyleri, sunulan mal ve hizmetlerin özelliklerinden kaynaklanan bir gereklilik olarak karşımıza çıkmaktadır. Bu sebeple araştırmanın amacını yiyecek içecek hizmetleri alanında görevli mutfak çalışanlarının yaratııııı algı düzeylerinin demografik faktörler açııından incelenmek oluşturmaktadır. Araştırmanın evrenini Türkiye'de yiyecek ve içecek hizmetleri alanında çalışan mutfak çalışanları oluşturmaktadır. Araştırma kapsamında çeşitli pozisyonlarda görevli 400 mutfak çalışanına anket formu yardımıyla elde edilen veriler ile ilgili yüzde, frekans, standart sapma, ortalama değerlere yer verilmektedir. Daha sonra çalışanlarının cinsiyet, yaş aralığı, eğitim seviyesi, mesleki deneyim, yiyecek içecek işletmesi türü, çalıştı̆̆ı pozisyon ve pozisyondaki çalışma süresi değişkenleri ile ilgili bağımsız örneklem $\mathrm{t}$-testi ve tek yönlü varyans analizi (Anova) sonuçları yer almaktadır. Araştırmada mutfak çalışanlarının yaratııılık algı düzeyinin yüksek seviyede olduğu tespit edilmiştir. Mutfak çalışanlarında yaratıclık algı düzeyinin cinsiyet, yaş aralığı, eğitim seviyesi, mesleki deneyim, yiyecek içecek işletmesi türü, çalıştığı pozisyon ve çalışma süresi değişkenlerine göre anlamlı düzeyde farkılıaştığı sonucuna ulaşılmışır. Ayrıca araştırma kapsamında bazı önerilere yer verilmekte olup, araştırmanın hem alan yazına hem de diğer araştırmacılara katkı sağlayacağı düsünülmektedir.

Jel Kodları: L83, L66, D23.

Anahtar Kelimeler: Mutfak Çalışanları, Yaratııılık Algı Düzeyleri, Gastronomi ve Mutfak Sanatları

\footnotetext{
${ }^{1}$ Dr. Öğr. Üyesi, Artvin Çoruh Üniversitesi, Uygulamalı Bilimler Yüksekokulu, Gastronomi ve Mutfak Sanatları Bölümü, ORCID:0000-0002-1523-8498, oganyener@gmail.com, 05319693939
}

Citation/Atıf: Oğan, Y. (2021). Mutfak çalışanlarının yaratıclık algı düzeyleri üzerine bir araştırma. Fiscaoeconomia, 5(2), 756-768. doi: 10.25295/fsecon.891984 
Oğan, Y. (2021). Mutfak çalışanlarının yaratııılık algı düzeyleri üzerine bir araştırma. Fiscaoeconomia, 5(2), 756-768. doi: 10.25295/fsecon.891984

\begin{abstract}
The concept of creativity, which is effective in the emergence of a new product by using thought and imagination, contributes to the development of an innovative understanding in the working environment. In the development of this innovative understanding, the creativity level of the culinary employees in the field of food and beverage services emerges as a necessity arising from the characteristics of the goods and services offered. For this reason, the aim of the study is to examine the creativity perception levels of culinary employees in the field of food and beverage services in terms of demographic factors. The universe of the research consists of culinary employees working in the field of food and beverage services in Turkey. Within the scope of the research, the percentage, frequency, standard deviation and average values are included in relation to the data obtained by applying a survey form to 400 culinary employees in various positions. And then, the independent sample t-test and one way variance analysis (Anova) results regarding the variables of the employees' gender, age range, education level, professional experience, type of food and beverage business, position and duration of work are included. In the study, it was determined that the creativity perception level of the culinary employees is at a high level. It was concluded that the creativity perception level of culinary employees differed significantly according to the variables of gender, age range, education level, professional experience, type of food and beverage business, position and duration of work. In addition, some suggestions are included within the scope of the research, and it is thought that the research will contribute to both the literature and other researchers.
\end{abstract}

Jel Codes: L83, L66, D23.

Keywords: Culinary Employees, Creativity Perception Levels, Gastronomy and Culinary Arts.

\title{
1. Giriş
}

İşletmeler açısından yeniliğin en önemli kaynaklardan biri olduğu düşünülen yaratıcılık kavramı; işletmelerde çalışan bireylerin oluşturduğu fikir, fayda, değer, hizmet, yeni ürün veya süreç olarak ifade edilebilmektedir (Çekmecelioğlu, 2002; Şengül, 2015). Çalışanlarda yaratıcılığın oluşması ve gelişebilmesi için cesaret, hoşgörü, inanma, kararlılık, aidiyet, özgürlük gibi pek çok unsur önem taşımaktadır (Marşap, 1999). Başka bir anlatımla bir işletmenin atmosferi ve işletmede çalışanların tutum ve davranış düzeyi yaratıcılığı doğrudan etkileyebilmektedir. İşletmelerin yeni ürün geliştirme, rekabet üstünlüğü sağlama, büyüyebilme gibi amaçları gerçekleştirebilmesinde ise yaratıcı bir kimliğe sahip olmaları stratejik açıdan önem taşımaktadır. Yine işletmelerin üretim, gelişim, sürdürülebilirlik, kar, müşteri tatmini gibi hem özel hem de genel amaçlarına ulaşmaları yaratıcılığın tespiti ve yaratıcılıktan yararlanma sayesinde gerçekleşmektedir (Kovancı, 1997; Samen, 2008). Bu sebeplerle işletmeler, çalışanlarını yaratıcılık konusunda desteklemeli ve teşvik etmelidir.

İnsanların gezmek, görmek, dinlenmek ve eğlenmek amaçlı yaptıkları seyahat ve konaklamaları kapsayan turizm faaliyetleri içerisinde yiyecek içecek işletmeleri önemli bir yer tutmaktadır (Bağcı ve Aydoğdu Bağcı, 2017; Baki, 2020). Günümüzde yiyecek içecek işletmeleri başta turizm sektörü olmak üzere çeşitli ve farklı alanlarda faaliyetlerini sürdürmektedir. Dolayısıyla sunulan mal ve hizmetin soyut olduğu ve insan odaklılık özelliği ile yiyecek içecek hizmeti sunan işletmeler bağımsız bir işletme olabildiği gibi konaklama işletmesi, fabrika, okul 
Oğan, Y. (2021). Mutfak çalışanlarının yaratııılık algı düzeyleri üzerine bir araştırma. Fiscaoeconomia, 5(2), 756-768. doi: 10.25295/fsecon.891984

gibi kuruluşların bünyesinde bir bölüm olarak da faaliyet gösterebilmektedir. Yiyecek içecek işletmeleri "temel amacı konukların yeme-içme gereksinimlerini karşılamak olan ekonomik, sosyal, hizmet kalitesi, menü gibi belirli standartları benimseyerek yiyecek ve içeceklerin hijyensanitasyon kurallarına uygun bir şekilde hazırlandığı ve sunulduğu işletmeler" olarak tanımlanabilmektedir (Oğan, 2020: 4). Tanımdan anlaşılacağı üzere yiyecek içecek işletmelerinin en önemli özelliği ürettikleri mal ve hizmetleri konuklarına sunmaları olarak ifade edilebilir. Yiyecek içecek işletmelerinde üretim ise planlama ile başlayan satın alma, depolama, hazırlama, sunum, yıkama şeklinde sıralanan iş basamakları ile mutfak organizasyonu bünyesinde gerçekleştirilmektedir. Dolayısıyla söz konusu bu işlemlerin başarılı bir şekilde gerçekleşebilmesi için mutfak ortamının uygun ekipmanlarla donatılması gerekmektedir (Sak, 2014). Yiyecek içecek işletmelerinin kar elde etmesi, hizmet kalitesi ve konuklarına daha iyi hizmet sunması başarılı bir mutfak organizasyonu sayesinde gerçekleşmektedir. Mutfaklarda görevli çalışanların emeği ve yaratıcılığı sayesinde ise yemeklerin görünümü, lezzeti, sunumu ile ilgili başarılı ve etkili sonuçlara ulaşılabilmektedir (Doğdubay ve Karan, 2017; Oğan, 2020). Bu sebeplerle yaratıcı bir mutfak organizasyon yapısı ile yiyecek içecek işletmeleri hem ekonomik hem de beşeri açıdan pek çok fayda sağlayabilmektedir. Bu faydalardan bazıları yeni ve gelişmiş ürünler, maliyetlerin azalması, işe devamsızlık ve iş gücü devir hızında azalma, başarılı bir organizasyon tasarımı, üst düzey düşünme becerisi, liderlik becerisi, rasyonel karar verme, takım çalışması, işbirliği, motivasyon, güven şekilde sıralanabilmektedir (Basadur, 1997). Bu bağlamda yiyecek içecek hizmetleri alanında çalışanların yaratıcılık düzeyi mutfak sanatlarının gelişmesine ve değişmesine etki eden en önemli faktörlerden biri olduğu ifade edilebilmektedir.

Son yıllarda iş dünyasında yaygın olarak kullanılan ve önem verilen bir konu olan yenilik (inovasyon) unsurunun kaynağını yaratıcılık oluşturmaktadır. Yaratıcılık kavramı yeni bir şey ortaya koymak amacıyla düşünce ve hayal gücünden yararlanılmasıdır. Dolayısıyla çalışma hayatında yenilikçi bir anlayışın gelişmesinde yaratıcık önemli bir rol üstlenmektedir. Yiyecek içecek hizmeti alanında emeğin yoğun olarak sunulduğu ve konuk beklenti düzeyinin yüksek olduğu dikkate alındığında mutfak organizasyonun işleyişi ile ilgili unsurların kusursuz işlemesi gerekmektedir. Bunun yanı sıra mutfak çalışanlarının yaratıcılık düzeyleri işletme başarısına doğrudan yansıyabilmektedir. Bu sebeplerle yiyecek içecek hizmetleri alanında görevli mutfak çalışanlarının yaratıcılık algı düzeylerinin demografik faktörler açısından incelenmesi önem arz etmektedir. Dolayısıyla yiyecek içecek hizmetleri alanında görevli mutfak çalışanlarının yaratıcılık algı düzeylerinin demografik faktörler açısından incelemek amacıyla yapılan bu araştırmanın temel problemini; mutfak çalışanlarının yaratıcılık algılarına ne düzeyde sahip oldukları oluşturmaktadır. Araştırmanın temel problemi doğrultusunda alt problemleri aşağıda maddeler halinde sıralanmaktadır.

- Yaratıcılık algı düzeyi ile cinsiyet grupları arasında farklılık var mıdır?

- Yaratıcılık algı düzeyi, yaş aralığına göre değişmekte midir?

- Yaratıcılık algı düzeyi, eğitim durumuna göre farklılık göstermekte midir?

- Yaratıcılık algı düzeyi ile mesleki deneyim süresi arasında farklılık var mıdır?

- Yaratıcılık algı düzeyi, yiyecek içecek işletmesi türüne göre farklııık göstermekte midir?

- Yaratıcılık algı düzeyi ile çalışılan pozisyon arasında bir farklılık var mıdır?

- Yaratıcılık algı düzeyi çalışılan pozisyondaki süreye göre farklılık göstermekte midir? 
Oğan, Y. (2021). Mutfak çalışanlarının yaratııılık algı düzeyleri üzerine bir araştırma. Fiscaoeconomia, 5(2), 756-768. doi: 10.25295/fsecon.891984

\section{Literatür Taraması}

Amabile ve arkadaşları (1996) iş ortamı değişkenleriyle yaratııılık arasındaki ilişki üzerine yaptığı bir çalışmada ana iş ortamını; yaratıcılı̆̆ı teşvik edilmesi (cesaretlendirme, iletişim, ödüllendirme vb.), otonomi ve özgürlük (karar verme, inisiyatif vb.), kaynaklar (bilgi, donanım, araç-gereç vb.), baskılar (aşırı iş yükü, işin zorluğu vb.) ve örgütsel engeller (yönetim, çevre, toplumsal, bireysel vb.) olarak beş başlıkta toplamıştır. Dolayısıyla mutfak organizasyonunda iş ortamının bu çerçevede tasarlanması yaratıcılığa olumlu yönde yansıyacağı şeklinde ifade edilebilmektedir. Acuner ve arkadaşları (2004) çalışmasında yaratıcılığı etkileyen örgütsel kaynaklı unsurları; eğitim ve gelişim, motivasyon ve ödül, katılımcı yönetim ve terfi, yönetim desteği, etkileşimi, iletişim ve esneklik olarak ifade etmiştir. Bu durum mutfak organizasyonu açısından ele alındığında örgütsel kaynaklı unsurların düzenlenmesi ile ilgili mutfak çalışanları yaratıcılığının yakın bir ilişkisi bulunmaktadır. Dikici (2006) lise son sınıf öğrencileri üzerine yaptığı bir çalışmada sanat eğitimi alan öğrenciler, sanat eğitimi almayan öğrencilere göre yaratıcı olduklarını tespit etmiştir. Bu durum mutfak çalışanları açısından ele alındığında mesleki açıdan eğitim alan çalışanların daha yaratıcı olabilecekleri söylenebilmektedir. Samen (2008) işletmelerde yaratıcılığı engelleyen başlıca faktörleri yönetim, örgüt, toplum, kültür, bireysel kaynaklı olarak sıralamıştır. Mutfak organizasyonu açısından bu engellerin kaldırılması yaratıcılığın gelişmesine önemli ölçüde katkı sağlayacağı şeklinde bir çıkarımında bulunabilmektedir. Akdoğan ve Kale (2011) karar süreçlerinde katılımcı bir anlayış, bağımsız bir çalışma ortamı, kuralların ölçülü olduğu örgüt yapısının yaratıcılık için uygun olduğunu belirtmiştir. Dolayısıyla mutfak alanlarındaki çalışma ortamında özgürlükçü bir anlayış ve katılımcı bir yönetim anlayışının olması yaratıcılığa olumlu olarak yansıyabilmektedir. Peng ve arkadaşları (2012) mutfak çalışmalarında zaman sınırlaması, mesleki beceri, pazarın kabulü, tecrübe ve kültür unsurlarını mutfakta yaratıcılığın ilkeleri olarak belirtmiştir. Kesici ve Önçel (2015) aş̧̧ılar ile ilgili yaptığı bir çalışmada bağımsız bir iş ortamının sağlanması ile hem çalışanların yaratıcılığı hem de işletmelerin gelişimi açısından olumlu sonuçlar elde edileceğini belirtmiştir. Boz (2019) gastronomi alanında eğitim alan öğrencilerin yaratıcı düşünme düzeylerini incelediği çalışmasında cinsiyet, sınıf düzeyi, kardeş sayısı, mezun olduğu okul, anne-baba iş ve eğitim durumu gibi değişkenlere göre anlamlı ilişkiler tespit etmiştir. Bu bağlamda ilgili çalışmalar incelendiğinde yaratıcılık konusunda pek çok farklı alanda çalışma olmasına rağmen yiyecek içecek hizmeti alanında görevli olan mutfak çalışanlarının yaratıcılık algı düzeylerinin demografik faktörler açısından incelenmesi ile ilgili sınırlı düzeyde çalışmalar bulunmaktadır. Dolayısıyla bu araştırmanın ilgili alan yazına ve diğer araştırmalara katkı sağlaması düşünülmektedir.

\section{Yöntem}

$\mathrm{Bu}$ araştırma yiyecek içecek hizmetleri alanında görevli mutfak çalışanlarının yaratıcılık algı düzeylerinin demografik faktörler açıdan incelemek amacıyla yapılmıştır. Betimsel araştırmalar ile olayların, objelerin, varlıkların, kurumların, grupların ve çeşitli alanların "ne" olduğunu açıklamaya çalışılmaktadır (Karasar, 2006). Bu sebeple araştırma modeli mevcut durumu ortaya koyması bakımından betimsel tarama deseninde bir araştırma olma özelliği taşımaktadır. 
Oğan, Y. (2021). Mutfak çalışanlarının yaratııılık algı düzeyleri üzerine bir araştırma. Fiscaoeconomia, 5(2), 756-768. doi: 10.25295/fsecon.891984

\subsection{Evren ve Örneklem}

Araştırmanın evrenini Türkiye'de yiyecek içecek hizmetleri alanında faaliyet gösteren çeşitli işletmelerde görevli mutfak çalışanları oluşturmaktadır. Türkiye'de yiyecek içecek hizmetleri alanında görevli mutfak çalışanları ile ilgili evreni temsil edecek örneklemin seçilmesinde herhangi bir şekilde evrenin bir parçasının seçildiği rastlantısal örnekleme tekniği kullanılmaktadır (Arlı ve Nazik, 2001). Araştırmanın evrenini 0,05 hata payı ve \%95 güven aralığında 384 örneklem sayısı evreni temsil edebilmektedir (Cohen, Manion ve Morrison, 2007; Ural ve Kılıç, 2013). Bu sebeple araştırmada toplam 400 mutfak çalışanına ulaşılmış olup araştırmanın evrenini temsil ettiği kabul edilmiştir.

\subsection{Verilerin Toplanması}

Araştırmada veriler, Çavuş (2006) tarafından geliştirilen "Örgütsel Yaratıcılık Ölçeği" araştırmanın amacına uygun olarak yiyecek içecek hizmeti alanında görevli mutfak çalışanlarına uyarlanarak elde edilmiştir. Anket formu iki bölümden oluşmakta olup, birinci bölümde çalışanların demografik özelliklerinden cinsiyet, yaş aralığı, eğitim düzeyi, mesleki deneyimi, mesleki pozisyonu, çalıştığı işletme türü ve işletmede çalışma süresi ile ilgili özellikleri belirlenmektedir. İkinci bölümde ise çalışanların yaratıcılık algı düzeyi ile ilgili görüşlerini belirlemek amacıyla 5'li Likert tipinde toplam 21 madde yer almaktadır. Maddeler katılım derecesine göre "kesinlikle katılıyorum, katılıyorum, kararsızım, katılmıyorum ve kesinlikle katılmıyorum" olarak yanıtlanmaktadır.

Anket formunun etik açıdan uygunluğu için Artvin Çoruh Üniversitesi Bilimsel Araştırma ve Yayın Etik Kuruluna başvuru yapılmış olup 25 Kasım 2020 tarihinde yapılan toplantıda etik kurul izni alınmıştır. Daha sonra "Google Forms" uygulaması yardımıyla dijital ortama aktarılan anket formu, 2021 yılı Ocak ve Şubat ayı içerisinde mutfak çalışanlarına uygulanarak veriler toplanmıştır.

\subsection{Verilerin Analizi}

$\mathrm{Bu}$ araştırmada elde edilen verilerin analizi için sosyal bilimler için istatiksel analiz (Spss) programı kullanılmıştır. Anket formunda yer alan bulguların yorumlanmasında frekans, yüzde dağılımı, ortalama ve standart sapma gibi betimsel istatistik değerlerinden yararlanılmıştır. Araştırmada kullanılan değerlendirme ölçeğinin iç tutarlılık katsayısı (Cronbach's Alpha) incelenerek $\alpha=0.905$ olduğu tespit edilmiştir. Bu değer, ölçeğin güvenilir ve aynı zamanda kararlı bir ölçme aracı olduğunu göstermektedir. Mutfak çalışanlarının yaratıcılık düzeyleri ile ilgili görüşleri Likert ölçeğine göre aritmetik ortalamaların değerlendirme aralığı için Aralık Genişliği=(Dizi Genişliği)/(Yapılacak Grup Sayısı) formülünden yararlanılarak, beşli Likert ölçeğinin aralık genişliği $0.80(5-1=4=4 / 5=0.80)$ bulunmuştur. Çalışanların yaratıcılık düzeyleri ile cinsiyet, yaş aralığı, eğitim düzeyi, mesleki deneyimi, mesleki pozisyonu, çalıştığı işletme türü ve işletmede çalışma süresi değişkenlerine göre karşılaştırılması amacıyla verilerin normal dağılım gösterip göstermediğine ilişkin Skewness (,-587 ile 1,323) ve Kurtosis (1,436 ile ,-563) puanları dikkate alındığında değişkenlerin $-1,5$ ile $+1,5$ olduğu için normal dağılım gösterdiği kabul edilmiştir (Tabachnick ve Fidell, 2013). Bu nedenle çalışanların yaratıcılık düzeylerinin iki kategoriden oluşan cinsiyet değişkeni açısından karşılaştırılması amacıyla Bağımsız Örneklem T-Testi, ikiden fazla kategori oluşturan diğer değişkenler açısından 
Oğan, Y. (2021). Mutfak çalışanlarının yaratııılık algı düzeyleri üzerine bir araştırma. Fiscaoeconomia, 5(2), 756-768. doi: 10.25295/fsecon.891984

değerlendirilmesi amacıyla Tek Yönlü Varyans (Anova) Analizi uygulanmıştır (Büyüköztürk, 2009).

\section{Bulgular}

\subsection{Mutfak Çalışanlarının Demografik Özellikleri}

Araştırmaya katılan mutfak çalışanlarının demografik özelliklerine ilişkin frekans, yüzde, ortalama ve standart sapma değerlerine Tablo 1'de yer verilmektedir.

Tablo 1. Mutfak Çalışanlarının Demografik Özellikleri

\begin{tabular}{|c|c|c|c|c|c|c|c|}
\hline & & $f$ & $\%$ & & & $f$ & $\%$ \\
\hline \multirow{2}{*}{ Cinsiyet } & Kadın & 208 & 52,0 & \multirow{9}{*}{$\begin{array}{l}\text { Yiyecek İçecek } \\
\text { İşletmesi Türü }\end{array}$} & & & \\
\hline & Erkek & 192 & 48,0 & & Otel & 128 & 32,0 \\
\hline \multirow{7}{*}{ Yaş } & $18-22$ & 76 & 19,0 & & Restoran & 88 & 22,0 \\
\hline & $23-27$ & 80 & 20,0 & & Lokanta & 16 & 4,0 \\
\hline & $28-32$ & 48 & 12,0 & & Kafe & 48 & 12,0 \\
\hline & $33-37$ & 100 & 25,0 & & Pastane & 57 & 14,2 \\
\hline & $39-45$ & 66 & 16,5 & & Catering & 15 & 3,8 \\
\hline & $46-52$ & 18 & 4,5 & & Ev Mutfağı & 21 & 5,2 \\
\hline & 53 ve üzeri & 12 & 3,0 & & Kamu Kuruluşu & 27 & 6,8 \\
\hline \multirow{6}{*}{$\begin{array}{l}\text { Eğitim } \\
\text { Düzeyi }\end{array}$} & ilkokul & 28 & 7,0 & \multirow{6}{*}{$\begin{array}{l}\text { Çalışılan } \\
\text { Pozisyon }\end{array}$} & Aşçı Başı & 52 & 13,0 \\
\hline & Ortaokul & 76 & 19,0 & & Kısım Şefi & 116 & 29,0 \\
\hline & Lise & 140 & 35,0 & & Aşçı & 122 & 30,5 \\
\hline & Ön Lisans & 96 & 24,0 & & Aşçı Yardımcısı & 68 & 17,0 \\
\hline & Lisans & 42 & 10,5 & & Eğitmen Şef & 21 & 5,2 \\
\hline & Lisansüstü & 18 & 4,5 & & Stajyer & 21 & 5,2 \\
\hline \multirow{5}{*}{$\begin{array}{l}\text { Mesleki } \\
\text { Deneyim }\end{array}$} & $0-5 \mathrm{yll}$ & 160 & 40,0 & \multirow{5}{*}{$\begin{array}{l}\text { Çalıştığı } \\
\text { Pozisyondaki } \\
\text { Süre }\end{array}$} & 1 yıldan daha az & 100 & 25,0 \\
\hline & 6-10 yıl & 112 & 28,0 & & $1-3 \mathrm{yll}$ & 124 & 31,0 \\
\hline & 10-15 yıl & 48 & 12,0 & & 4-6 yıl & 84 & 21,0 \\
\hline & $16-20$ & 35 & 8,8 & & 7-9 yıl & 38 & 9,5 \\
\hline & 21 yıl ve üstü & 45 & 11,2 & & 10 yıl ve üzeri & 54 & 13,5 \\
\hline \multicolumn{2}{|l|}{ Toplam } & 400 & 100 & & & 400 & 100 \\
\hline
\end{tabular}

Tablo 1 incelendiğinde araştırmaya katılan mutfak çalışanlarının \%52'sinin kadın ve \%48'inin erkek bireylerden oluşmaktadır. Dolayısıyla çalışanların kadın erkek oranı birbirine yakın dağılım göstermektedir. Mutfak çalışanlarının \%13'ü aşçı başı, \%29'u kısım şefi, \%30,5'i aşçı, \%17'si aş̧̧ı yardımcısı, \%5,2'si eğitmen ve \%5,2'si stajyer pozisyonlarında çalışmaktadır. Çalışanların pozisyonları incelendiğinde büyük bir bölümü aş̧̧ ve üzeri statüde görev yapmaktadır. Mutfak çalışanlarının yaş grubu dikkate alındığında \%19'u 18-22, \%20'si 23-27, $\% 12$ 'si $28-32, \% 25$ ' i 33-37, \%16,5'i 39-45, \%4,5'i 46-52 ve \%3'ü ise 53 ve üzeri yaş aralığında olduğu görülmektedir. Dolayısıyla çalışanların büyük bir bölümü 45 yaşın altında bireyler oluşmaktadır. Çalışanların eğitim düzeyi incelendiğinde ise \%61 gibi büyük bir bölümü orta öğretim düzeyinde iken \% 39'u üniversite düzeyinde olduğu görülmektedir. Bu durum çalışanların belirli bir eğitim seviyesinde olduğu şeklinde ifade edilebilmektedir. Çalışanların \%68'lik büyük bir bölümü 0-10 yıl, \%12'si 10-15 yıl, 8,8'i 16-20 yıl ve 11,2's, 21 ve üzeri yıl mesleki deneyim süresi bulunmaktadır. Ayrıca çalışanların çalıştığı pozisyondaki geçirdiği süre ise \%25'i 1 yıldan az, \%31'i 1-3 yıl, \%21'i 4-6 yıl, \%9,5'i 1-9 yıl ve \%13,5'i 10 yıl ve üzeri olarak tespit edilmiştir. Son olarak çalışanların \%32'si otel, \%22'si restoran, \%4'ü lokanta, \%12'si kafe, \%14,2'si pastane, \%3,8'i catering, 5,2'si ev mutfağı ve 6,8'i kamu kuruluşu bünyesinde görev 
Oğan, Y. (2021). Mutfak çalışanlarının yaratııılık algı düzeyleri üzerine bir araştırma. Fiscaoeconomia, 5(2), 756-768. doi: 10.25295/fsecon.891984

yapmaktadır. Dolayısıyla çalışanların belirli bir düzeyde iş tecrübesine sahip olduğu ve yiyecek içecek hizmeti sunan farklı işletme türlerinde görev yapmaktadır.

\subsection{Mutfak Çalışanlarının Yaratıcılık Algı Düzeyi İle İlgili Görüşleri}

Yiyecek içecek hizmetleri alanında görev yapan mutfak çalışanlarının yaratıcılık algı düzeyi ile ilgili cevaplara ilişkin yüzde, ortalama ve standart sapma değerlerine Tablo 2'de yer verilmektedir.

Tablo 2. Mutfak Çalışanlarının Yaratıcılık Algı Düzeyleri İle illgili Görüşleri ( $n=400)$

\begin{tabular}{|c|c|c|c|c|c|c|c|c|}
\hline \multirow{2}{*}{\multicolumn{2}{|c|}{ Yaratıcılık Algı Düzeyleri }} & \multicolumn{5}{|c|}{$\%$} & \multirow{2}{*}{$\bar{x}$} & \multirow{2}{*}{ Sd } \\
\hline & & 1 & 2 & 3 & 4 & 5 & & \\
\hline 1 & İ̧̧letmemizin herkesçe paylaşılan yaratıcı bir vizyonu vardır. & 4,2 & 5,8 & 13,0 & 44,5 & 32,5 & |3,95 & $\mid 1,02$ \\
\hline 2 & İ̧letmemizde öğrenme teşvik edilir. & 3,5 & 2,5 & 11,0 & 50,0 & 33,0 & 4,06 & ,937 \\
\hline 3 & Yeni fikirler her zaman değerlendirilir. & 3,2 & 5,8 & 4,5 & 46,5 & 40,0 & 4,15 & 964 \\
\hline 4 & Yaratıcı olmak için her zaman cesaretlendiriliriz. & 5,4 & 10,6 & 7,0 & 45,5 & 31,5 & 3,88 & 1,12 \\
\hline 5 & İşletmemizde yaratıcılık için uygun ortam hazırlanmıştır. & 5,8 & 10,2 & 13,0 & 50,8 & 20,2 & 3,70 & 1,09 \\
\hline 6 & Yaratıcı fikirler için yeterli zaman sağlanmaktadır. & 8,0 & 13,2 & 15,8 & 40,5 & 22,5 & 3,56 & 1,19 \\
\hline 7 & İ̧̧letmemizde bilginin paylaşım düzeyi yüksektir. & 5,5 & 6,5 & 12,0 & 50,8 & 25,2 & 3,85 & 1,04 \\
\hline 8 & Düşüncelerimizi her zaman açıkça ifade edebiliriz. & 6,0 & 7,0 & 8,0 & 52,05 & 26,5 & 3,86 & 1,07 \\
\hline 9 & Yaratıcılık personel politikasının bir parçasıdır. & 4,0 & 12,0 & 11,0 & 48,0 & 25,0 & 3,78 & 1,07 \\
\hline 10 & Yaratıcı düşünceler performans değerlemede dikkate alınır. & 18,0 & 37,8 & 13,0 & 23,8 & 7,5 & 2,65 & 1,23 \\
\hline 11 & işletmemde yaratıcılığı engelleyen örgütsel ve yönetsel faktörler aza & 6,2 & 19,8 & 19,8 & 38,2 & 16,0 & 3,37 & 1,16 \\
\hline 12 & Yaratıcılığı geliştirecek eğitimler ve gerekli destekler verilir. & 6,0 & 13,2 & 20,8 & 43,0 & 17,0 & 3,51 & 1,11 \\
\hline 13 & Çalışanların kendi işi dışındaki işler içinde fikir üretmeleri teşvik edilir. & 11,0 & 20,0 & 10,0 & 39,5 & 19,5 & 3,37 & 1,30 \\
\hline 14 & Başarısızlıklar görmezden gelinip başarılar ödüllendirilir. & 10,5 & 33,0 & 17,0 & 30,5 & 9,0 & 2,96 & 1,18 \\
\hline 15 & Yaratıcı düşünceyi artıracak bağımsız çalışma ortamı sunulmaktadır. & 8,2 & 9,8 & 17,0 & 47,0 & 18,0 & 3,56 & 1,13 \\
\hline 16 & Yetki ve sorumluluğun artması çalışanları daha yaratıcı yapabilir. & 3,8 & 8,2 & 9,2 & 44,0 & 34,8 & 3,97 & 1,05 \\
\hline 17 & İ̧letmemizde yaratıcı sorun çözme teknikleri sıklıkla kullanılır. & 7,5 & 10,8 & 6,8 & 53,0 & 22,0 & 3,71 & 1,14 \\
\hline 18 & İ̧letmemizde yaratıcılık için her zaman maddi ve manevi destek sağlanır. & 8,2 & 17,0 & 14,8 & 31,0 & 29,0 & 3,55 & 1,29 \\
\hline 19 & Çalışanlardan beklenen yüksek performans yaratıcılığı artırmaktadır. & 3,0 & 17,2 & 9,8 & 51,0 & 19,0 & 3,65 & 1,06 \\
\hline 20 & Yaratıcı düşünceler karşılıklı güven içerisinde ele alınır. & 5,2 & 5,2 & 9,5 & 57,0 & 23,0 & 3,87 & 996 \\
\hline 21 & işletmemizde yeni fikirlere kuşkuyla yaklaşılır. & 18,0 & 43,0 & 9,5 & 22,0 & 7,5 & 2,58 & 1,22 \\
\hline
\end{tabular}

Tablo 2 incelendiğinde mutfak çalışanları sırasıyla "Yeni fikirler her zaman değerlendirilir.", "İ̧̧letmemizde öğrenme teşvik edilir.", "Yetki ve sorumluluğun artması çalışanları daha yaratıcı yapabilir." ve "Işletmemizin herkesçe paylaşılan yaratıcı bir vizyonu vardır.", ( $\bar{x}=4,15-4,06$ 3,97-3,95) ifadelerine en yüksek ortalama ile katılmaktadır. "Yaratıcı düşünceler performans değerlemede dikkate alınır.", "Iş̧letmemizde yeni fikirlere kuşkuyla yaklaşılır." , "Başarısızlıklar görmezden gelinip başarılar ödüllendirilir.", "İşletmemde yaratıcılığı engelleyen örgütsel ve yönetsel faktörler aza indirgenir." ve "Çalışanların kendi işi dışındaki işler içinde fikir üretmeleri teşvik edilir." ( $\bar{x}=2,65-2,58-2,96-3,37-3,37)$ ifadelerine ise en düşük ortalama ile katıldıkları tespit edilmiştir. Dolayısıyla işletmelerde paylaşımcı bir vizyon yapısı, fikirlere önem verilmesi, öğretici olunması, yetki devri ve sorumluk kavramları yaratıcılığı olumlu olarak yansımaktadır. Ayrıca işletmelerde cesaretlendirme, uygun ortam, bilginin paylaşımı, düşünce özgürlügü̈, personel politikası, eğitim ve destekler, bağımsız çalışma, sorun çözme teknikleri, maddi ve 
Oğan, Y. (2021). Mutfak çalışanlarının yaratııılık algı düzeyleri üzerine bir araştırma.

Fiscaoeconomia, 5(2), 756-768. doi: 10.25295/fsecon.891984

manevi destek, yüksek performans beklentisi ve güven duygusu ile ilgili ifadelere ortalamanın üstünde katıldıkları ve bu ifadelerin yaratıcılık algılarını olumlu yönde geliştirdiği ifade edilebilmektedir.

\subsection{Yaratıcılık Algı Düzeyi ile Mutfak Çalışanlarının Cinsiyet Değişkenine Göre Bağımsız Örneklem T-Testi Sonuçları}

Yiyecek içecek hizmetleri alanında görevli mutfak çalışanlarının yaratıcılık algı düzeyleri ile cinsiyet değişkeni arasında anlamlı bir farklılık gösterip göstermediğini belirlemek amacıyla yapılan Bağımsız Örneklem T-Testi sonucuna ilişkin bulgulara Tablo 3'te yer verilmektedir.

Tablo 3. Yaratıcılık Algı Düzeyi ile Cinsiyet Karşılaştırılması (T-Testi)

\begin{tabular}{|c|c|l|l|l|l|l|}
\hline Faktör & Cinsiyet & N & $\bar{x}$ & Sd & F & P \\
\hline \multirow{2}{*}{ Yaratıcılık Düzeyi Toplam Puanı } & Kadın & 208 & 3,30 &, 544 & \multirow{2}{*}{210,486} & \multirow{2}{*}{, 000} \\
\cline { 2 - 7 } & Erkek & 192 & 3,91 &, 159 & & \\
\hline \multicolumn{2}{|c|}{ Toplam } & $\mathbf{4 0 0}$ & & & & \\
\hline
\end{tabular}

Tablo 3 incelendiğinde mutfak çalışanlarının yaratıcılık algı düzeylerinin cinsiyet değişkenine göre anlamlı bir farklılık göstermektedir [t=210,486; $p<.05]$. Dolayısıyla mutfak çalışanlarının ortalamaları incelendiğinde kadınların $(\bar{x}=3,30 ; \mathrm{sd}=, 544)$ erkeklerden $(\bar{x}=3,91 ; \mathrm{sd}=, 159)$ daha düşük bir yaratıcılık algısına sahip oldukları ifade edilebilmektedir. Bu bağlamda erkek mutfak çalışanlarının yaratıcılık düzeyleri yüksek olup, yiyecek içecek işletmelerinin mutfak bölümüne yaratıcılık açısından kadın çalışanlara oranla daha fazla katkı sağladığı şeklinde yorumlanabilmektedir.

\subsection{Yaratıcılık Algı Düzeyi ile Mutfak Çalışanlarının Yaş Aralığı ve Eğitim Seviyesine Göre Tek Yönlü Varyans Analizi Sonuçları}

Yiyecek içecek hizmetleri alanında görevli mutfak çalışanlarının yaratıcılık algı düzeylerinin yaş aralıkları ve eğitim seviyesine göre karşılaştırması amacı ile ilişkisiz ölçümler için Tek Yönlü Varyans Analizi (Anova) sonuçlarına Tablo 4'te yer verilmektedir.

Tablo 4. Yaratıcılık Algı Düzeyi ile Yaş Aralığı ve Eğitim Seviyesi Karşılaştırılması (Anova)

\begin{tabular}{|l|l|l|l|l|l|l|}
\hline Yaş Aralığı & Varyansın Kaynağı & Kareler Toplamı & Sd & Kareler Ortalaması & F & P \\
\hline \multirow{2}{*}{$\begin{array}{l}\text { Yaratıcılık Düzeyi } \\
\text { Toplam Puanı }\end{array}$} & Gruplar arası & 75,692 & 5 & 15,138 & 220,166 &, 000 \\
\cline { 2 - 7 } & Gruplar içi & 27,091 & 394 &, 069 & & \\
\hline \multicolumn{2}{|c|}{ Toplam } & 102,783 & 399 & & & \\
\hline Eğitim Seviyesi & Varyansın Kaynağı & Kareler Toplamı & Sd & Kareler Ortalaması & F & P \\
\hline $\begin{array}{l}\text { Yaratıcılık Düzeyi } \\
\text { Toplam Puanı }\end{array}$ & Gruplar arası & 86,201 & 5 & 17,240 & 409,632 &, 000 \\
\cline { 2 - 8 } & Gruplar içi & 16,582 & 394 &, 042 & & \\
\hline \multicolumn{2}{|c|}{ Toplam } & 102,783 & 399 & & & \\
\hline
\end{tabular}

Tablo 4 incelendiğinde mutfak çalışanlarının yaş aralıkları ile yaratıcılık algı düzeyi toplam puanları arasında anlamlı bir fark olduğu tespit edilmiştir $(F=220,166 ; p<, 05)$. Dolayısıyla mutfak çalışanlarının yaşlarına göre yaratıcılık düzeyleri farklılaştığı belirtilebilmektedir. Yine Tablo 4'teki sonuçlara göre mutfak çalışanlarının eğitim düzeyi ile yaratıcılık algı düzeyi toplam 
Oğan, Y. (2021). Mutfak çalışanlarının yaratııılık algı düzeyleri üzerine bir araştırma.

Fiscaoeconomia, 5(2), 756-768. doi: 10.25295/fsecon.891984

puanları arasında anlamlı bir fark olduğu tespit edilmiştir ( $F=409,632 ; p<, 05)$. Bu durum mutfak çalışanlarının eğitim düzeyi, yaratıcılık düzeylerini olumlu yönde etkilediği şeklinde yorumlanabilmektedir.

\subsection{Yaratıcılık Algı Düzeyi ile Mutfak Çalışanlarının Mesleki Deneyim ve Yiyecek İçecek İşletmesi Türüne Göre Tek Yönlü Varyans Analizi Sonuçları}

Yiyecek içecek hizmetleri alanında görevli mutfak çalışanlarının yaratıcılık algı düzeyleri ile mesleki deneyim ve yiyecek içecek işletmesi türüne göre karşılaştırması amacı ile ilişkisiz ölçümler için Tek Yönlü Varyans Analizi (Anova) sonuçlarına Tablo 5'te yer verilmektedir.

Tablo 5. Yaratıcılık Algı Düzeyi ile Mesleki Deneyim ve Yiyecek İçecek İşletmesi Türü Karşılaştırılması (Anova)

\begin{tabular}{|c|c|c|c|c|c|c|}
\hline Mesleki Deneyim & Varyansın Kaynağı & Kareler Toplamı & Sd & Kareler Ortalaması & $\mathbf{F}$ & $\mathbf{P}$ \\
\hline \multirow{2}{*}{$\begin{array}{l}\text { Yaratıcılık Düzeyi } \\
\text { Toplam Puanı }\end{array}$} & Gruplar arası & 66,279 & 4 & 16,570 & 179,296 &, 000 \\
\hline & Gruplar içi & 36,504 & 395 & ,092 & & \\
\hline \multicolumn{2}{|l|}{ Toplam } & 102,783 & 399 & & & \\
\hline $\begin{array}{l}\text { Yiyecek İçecek } \\
\text { İşletmesi Türü }\end{array}$ & Varyansın Kaynağı & Kareler Toplamı & Sd & Kareler Ortalaması & $\mathbf{F}$ & $\mathbf{P}$ \\
\hline \multirow{2}{*}{$\begin{array}{l}\text { Yaratıcılık Düzeyi } \\
\text { Toplam Puanı }\end{array}$} & Gruplar arası & 72,232 & 7 & 10,319 & 132,404 &, 000 \\
\hline & Gruplar içi & 30,554 & 392 & ,078 & & \\
\hline \multicolumn{2}{|l|}{ Toplam } & 102,783 & 399 & & & \\
\hline
\end{tabular}

Tablo 5 incelendiğinde mutfak çalışanlarının mesleki deneyimi ile yaratıcılık algı düzeyi toplam puanları arasında anlamlı bir fark olduğu görülmektedir ( $F=179,296 ; p<, 05)$. Dolayısıyla mutfak çalışanlarının mesleki tecrübesi ile yaratıcılık düzeyleri arasında yakın bir ilişki bulunmaktadır. Yine Tablo 5'deki sonuçlara göre mutfak çalışanlarının görevli olduğu yiyecek içecek işletmesi türü ile yaratıcılık algı düzeyi toplam puanları arasında anlamlı bir fark olduğu tespit edilmiştir $(F=10,319 ; p<, 05)$. Bu durum yiyecek içecek işletmesinin konuklara sunduğu hizmetin özellikleri göz önünde bulundurulduğunda, mutfak çalışanlarının yaratıcılık düzeyini geliştirdiği şeklinde ifade edilebilmektedir.

\subsection{Yaratıcılık Algı Düzeyi ile Mutfak Çalışanlarının Çalıştığı Pozisyon ve Çalışma Süresine Göre Tek Yönlü Varyans Analizi Sonuçları}

Yiyecek içecek hizmetleri alanında görevli mutfak çalışanlarının yaratıcılık algı düzeyleri ile çalıştığı pozisyon ve çalışma süresine göre karşılaştırması amacı ile ilişkisiz ölçümler için Tek Yönlü Varyans Analizi (Anova) sonuçlarına Tablo 6'da yer verilmektedir. 
Oğan, Y. (2021). Mutfak çalışanlarının yaratııılık algı düzeyleri üzerine bir araştırma. Fiscaoeconomia, 5(2), 756-768. doi: 10.25295/fsecon.891984

Tablo 6. Yaratıcılık Algı Düzeyi ile Çalışılan Pozisyon ve Çalışma Süresi Karşılaştırılması (Anova)

\begin{tabular}{|c|c|c|c|c|c|c|}
\hline Çalışılan Pozisyon & Varyansın Kaynağı & Kareler Toplamı & Sd & Kareler Ortalaması & $\mathbf{F}$ & $\mathbf{P}$ \\
\hline \multirow{2}{*}{$\begin{array}{l}\text { Yaratıcılık Düzeyi } \\
\text { Toplam Puanı }\end{array}$} & Gruplar arası & 90,683 & 5 & 18,137 & 590,557 & ,000 \\
\hline & Gruplar içi & 12,100 & 394 & ,031 & & \\
\hline \multicolumn{2}{|l|}{ Toplam } & 102,783 & 399 & & & \\
\hline Çalışma Süresi & Varyansın Kaynağı & Kareler Toplamı & Sd & Kareler Ortalaması & $\mathbf{F}$ & $\mathbf{P}$ \\
\hline \multirow{2}{*}{$\begin{array}{l}\text { Yaratıcılık Düzeyi } \\
\text { Toplam Puanı }\end{array}$} & Gruplar arası & 76,847 & 5 & 19,212 & 292,592 & ,000 \\
\hline & Gruplar içi & 25,936 & 395 & ,066 & & \\
\hline \multicolumn{2}{|l|}{ Toplam } & 102,783 & 399 & & & \\
\hline
\end{tabular}

Tablo 6 incelendiğinde mutfak çalışanlarının çalıştığı pozisyon ile yaratıcılık algı düzeyi toplam puanları arasında anlamlı bir fark olduğu görülmektedir ( $F=590,557 ; p<, 05)$. Dolayısıyla mutfakta yapılan işin özelliklerine göre çalışanların yaratıcılık düzeyi farklılaşmaktadır. Yine Tablo 6'daki sonuçlara göre mutfak çalışanlarının çalıştığı pozisyondaki süre ile yaratıcılık algı düzeyi toplam puanları arasında anlamlı bir fark olduğu görülmektedir ( $F=292,592 ; p<, 05)$. Bu durum çalışılan pozisyondaki iş için harcanan zamanın çalışanların yaratıcılık düzeyini etkilediği şeklinde yorumlamak mümkündür.

\section{Sonuç ve Öneriler}

Yaratıcılık, günümüz çalışma ortamında yeniliğin kaynağını ve iş hayatında ayırt edici bir özelliği oluşturmaktadır. Emeğin yoğun olduğu sektörlerde, yaratıcılık anlayışının gelişmesi işletmelere belirgin bir şekilde faydalar sağlamaktadır. Bu sektörlerden biri olan yiyecek ve içecek üretiminin gerçekleştirdiği mutfak organizasyonlarında çalışanların yaratıcılık düzeyleri işletmeye değer katarak kar ve başarılarını doğrudan etkileyebilmektedir. Yiyecek içecek hizmetleri alanında görevli mutfak çalışanlarının yaratıcılık algı düzeylerinin demografik faktörler açıdan incelemek amacıyla yapılan bu araştırma kapsamında, mutfak çalışanlarının ortalamanın üzerinde bir yaratıcılık algı düzeyi bulunduğu tespit edilmiştir. Dolayısıyla mutfak çalışanlarının yüksek düzeyde yaratıcılığa sahip olması yiyecek içecek hizmeti sunan kuruluşlar açısından önem taşımaktadır.

Mutfak organizasyonunda görevli erkek çalışanlarının yaratıcılık düzeylerinin kadın çalışanlara oranla daha yüksek olması, erkek çalışanların yaratıcılık açısından mutfak bölümüne daha fazla katkı sağladığı şeklinde ifade edilebilmektedir. Mutfak çalışanlarının yaşlarına göre ise yaratıcılık düzeyleri farklılaşmaktadır. Bu durumu mutfak çalışanlarının mesleki tecrübesi ve çalıştığı pozisyondaki iş için harcanan zaman açısından yaratıcılık düzeyleri arasında yakın bir ilişki olması da desteklemektedir. Mutfak çalışanlarının eğitim durumları yaratıcılık düzeylerini olumlu yönde etkilemektedir. Yiyecek içecek işletmesinin türü mutfak çalışanlarının yaratıcılık düzeyini etkilemesi ise konuklara sunulan hizmet kalitesi özelliklerinin yaratıcılık düzeyini geliştirdiği şeklinde açıklanabilmektedir. Mutfakta yapılan işin özelliği dikkate alındığında çalışanların yaratıcılık düzeyi arasında farklılık görülmesi, çalışma ortamındaki görev tanımları ile yakından ilişkili olduğu şeklinde belirtilebilmektedir. Dolayısıyla mutfak çalışanlarının yaratıcılığını geliştirmede, iş ortamının çalışanlara göre tasarlanması ve yönetici tutumlarının 
Oğan, Y. (2021). Mutfak çalışanlarının yaratııılık algı düzeyleri üzerine bir araştırma.

Fiscaoeconomia, 5(2), 756-768. doi: 10.25295/fsecon.891984

çalışanları teşvik edici olması beklenmektedir. Ayrıca araştırmanın hem ilgili alan yazına hem de diğer araştırmacılara katkı sağlaması öngörülmektedir.

\section{Kaynakça}

Acuner, T., Birdoğan B. ve Cengiz E. (2004). Yaratıcı Örgüt Kültürü Faktörlerinin Belirlenmesi Üzerine Bir Araştırma. Atatürk Üniversitesi Sosyal Bilimler Enstitüsü Dergisi, 4 (2), 325340.

Ağalday, B. ve Dağlı, A. (2018). Öğretmenlerin Örgütsel Yaratıcılığa iliş̧kin Algılarının Çeşitli Değişkenlere Göre Incelenmesi. Sivas: Cumhuriyet Üniversitesi Yayıncılık.

Akdoğan, A. ve Kale, E. (2011). Konaklama İşletmelerinde Örgüt İçi Faktörlerin Yenilik Ve Yaratıcılık Performansına Etkisi, Nevşehir Üniversitesi Sosyal Bilimler Enstitüsü Dergisi, 1 (1), 165-186.

Amabile, T. M., Conti, R., Coon, H., Lazenby, J. ve Herron, M. (1996). Assessing The Work Environment For Creativity. Academy of Management Journal, 39 (5), 1154-1184.

Arlı, M. ve Nazik, H. (2001). Bilimsel Araştırmaya Giriş. Ankara: Gazi Kitabevi.

Bağcl, H. ve Aydoğdu Bağcl, S. (2017). Turizm Sektöründe Etkinlik Analizi: Türkiye Örneği. (Ed: Ayhan Bünyamin, Ay Mustafa, Avşaroğlu Selahattin, Akpınar Şerife) Sosyal ve Beşeri Bilimler Araştırmaları. Konya: Çizgi Kitabevi, 80-87.

Baki, R. (2020). Evaluating Hotel Websites Through the Use of Fuzzy AHP and Fuzzy TOPSIS. International Journal of Contemporary Hospitality Management, 32 (12), 3747-3765.

Basadur, M. (1997). Organizational Development Interventions For Enhancing Creativity in The Workplace. The Journal of Creative Behavior, 31 (1), 59-72.

Boz, N. (2019). Gastronomi ve Mutfak Sanatları Alanında Öğrenim Gören Öğrencilerin Yaratıcı Düşünme Düzeylerinin İncelenmesi (Yüksek Lisans Tezi). Denizli: Pamukkale Üniversitesi Sosyal Bilimler Enstitüsü.

Büyüköztürk, Ş. (2009). Veri Analizi El Kitabı. Ankara: Pegem Akademi.

Çavuş, M. F. (2006). İşletmelerde Personel Güçlendirme Uygulamalarının Örgütsel Yaratıcılık ve Yenilikçiliğe Etkileri Üzerine İmalat Sanayinde Bir Uygulama (Basılmamış Doktora Tezi). Konya: Selçuk Üniversitesi Sosyal Bilimleri Enstitüsü.

Çekmecelioğlu, H. G. (2002). Bireysel, Örgütsel Yaratıcılık ve Yaratıcılık İçin İş Çevresinin Düzenlenmesi: Bir Araştırma (Doktora Tezi). Kocaeli: Gebze Yüksek Teknoloji Enstitüsü Sosyal Bilimler Enstitüsü.

Cohen, L., Manion, L., ve Morrison, K. (2007). Research Methods in Education. Routledge/Taylor \& Francis Group.

Dikici, A. (2006). Sanat Eğitimi ve Öğrencilerin Yaratıcılık Düzeyleri. Eğitim ve Bilim Dergisi, 31 (139), 3-9.

Doğdubay, M. ve Karan, İ. (2017). Otel Mutfaklarında Sistematik İ̧̧yeri Düzenleme Planı (SiDP) Modelinin Uygulanması. Aydın Gastronmy Dergisi, 1 (1). 
Oğan, Y. (2021). Mutfak çalışanlarının yaratııılık algı düzeyleri üzerine bir araştırma. Fiscaoeconomia, 5(2), 756-768. doi: 10.25295/fsecon.891984

Karasar, N. (2006). Bilimsel Araştırma Yöntemleri. Ankara: Nobel Yayın Dağıtım.

Kesici, M. ve Önçel, S. (2015). Aşçıların Mesleki Özerklikleri İle Yaratıcılık Süreci ilişkisi. İşletme Fakültesi Dergisi, 16 (1), 23-45.

Kovancı, A. (1994). Yaratıcılık. Hava Harp Okulu Bülteni, 14 (37).

Marşap, A. (1999). Yaratıcı Liderlik. Ankara: Öncü Kitapları.

Oğan, Y. (2020). Yiyecek İçecek İşletmeleri. (Ed: Yener Oğan) Yiyecek Içecek Hizmetleri. Ankara: Nobel Akademik Yayıncılık, 1-23.

Peng, K.L., Lin, M.C. ve Baum, T. (2012). The Constructing Model Of Culinary Creativity: A Mixed Methods Approach. Quality and Quantity, 47(5), 2687-2707.

Sak, G. (2014). Mutfak Tasarımında Modüler Sistemlerin Kullanıcı Ergonomisi Açısından Değerlendirilmesi (Yüksek Lisans Tezi). İstanbul: İstanbul Kültür Üniversitesi Fen Bilimleri Enstitüsü.

Samen, S. (2008). İşletmelerde Yaratıcılığın Önemi. Çukurova Üniversitesi Sosyal Bilimler Enstitüsü Dergisi, 17 (2), 363-378.

Seçilmiş, C. , Kodaş, B. ve Kodaş, D. (2017). Örgütsel Öğrenme Yeteneği ve Yaratıcılık Süreci Iliş̧isi: Eskişehir'deki Mutfak Çalışanları Üzerine Bir Araştırma. Journal of Tourism and Gastronomy Studies, 5 (3), 150-167.

Şengül, C. M. (2015). Örgütlerde Yaratıcılık ve İnovasyonun Artırılmasına Yönelik Yaklaşımlar. Sosyal ve Beşeri Bilimleri Dergisi, 7 (2), 26-37.

Tabachnick, B. G. ve Fidell, L. S. (2013). Using Multivariate Statistics. United States: Pearson Education.

Ural, A. ve Kılıç, ì. (2013). Bilimsel Araştırma Süreci ve SPSS ile Veri Analizi. Ankara: Detay Yayıncilık.

Etik Beyanı: Bu çalışmanın tüm hazırlanma süreçlerinde etik kurallara uyulduğunu yazarlar beyan eder. Aksi bir durumun tespiti halinde Fiscaoeconomia Dergisinin hiçbir sorumluluğu olmayıp, tüm sorumluluk çalışmanın yazarlarına aittir.

Ethics Statement: The authors declare that ethical rules are followed in all preparation processes of this study. In case of detection of a contrary situation, Fiscaoeconomia has no responsibility and all responsibility belongs to the authors of the study. 
Oğan, Y. (2021). Mutfak çalışanlarının yaratııılık algı düzeyleri üzerine bir araştırma.

Fiscaoeconomia, 5(2), 756-768. doi: 10.25295/fsecon.891984

\section{An Investigation on the Creativity Perception Levels of Culinary Employees}

\section{Yener OĞAN}

\section{Extended Abstract}

Creativity is important in the development of an innovative understanding in food and beverage businesses. It defines it as businesses where food and beverages are prepared and served in accordance with hygiene-sanitation rules by adopting certain standards such as economic, social, service quality, menu, whose main purpose is to meet the eating and drinking needs of the guests. Considering that the labor is intensely offered in the field of food and beverage service and the level of guest expectation is high, the elements related to the functioning of the culinary organization must function perfectly. The aim of the study is to examine the creativity perception levels of culinary employees in the field of food and beverage services in terms of demographic factors.

The research model has the feature of being a descriptive study in terms of revealing the current situation. The universe of the research consists of culinary employees working in the field of food and beverage services in Turkey. Random sampling technique, which is one of the non-random sampling methods in which a part of the universe is selected in any way, is used in the selection of the sample that will represent the universe related to the culinary employees. The number of suitable samples that make up the universe of the research was determined as 400 individuals. In the research, the creativity scale was obtained by applying it to culinary employees in the field of food and beverage service. Independent sample t-test was applied to compare the creativity levels of the employees in terms of gender variable, and one way variance of analysis (Anova) was applied to evaluate them in terms of other variables.

In the study, it was determined that the creativity perception level of the culinary employees is at a high level. It was concluded that the creativity perception level of culinary employees differed significantly according to the variables of gender, age range, education level, professional experience, type of food and beverage business, position and duration of work. The creativity levels of employees in culinary organizations can directly affect their profits and success by adding value to the business. It is expected that the work environment is designed according to the employees and the managerial attitudes will encourage the employees in developing the creativity of culinary employees. In addition, it is thought that the research will contribute to both the literature and other researchers. 